$1-1-2006$

\title{
Current Practices in Engineering Capstone Education: Further Results From a 2005 Nationwide Survey
}

\author{
Jessica Wilbarger \\ Smith College \\ Susannah Howe \\ Smith College, showe@smith.edu
}

Follow this and additional works at: https://scholarworks.smith.edu/egr_facpubs

Part of the Engineering Commons

\section{Recommended Citation}

Wilbarger, Jessica and Howe, Susannah, "Current Practices in Engineering Capstone Education: Further Results From a 2005 Nationwide Survey" (2006). Engineering: Faculty Publications, Smith College, Northampton, MA.

https://scholarworks.smith.edu/egr_facpubs/51

This Conference Proceeding has been accepted for inclusion in Engineering: Faculty Publications by an authorized administrator of Smith ScholarWorks. For more information, please contact scholarworks@smith.edu 


\title{
Current Practices in Engineering Capstone Education: Further Results from a 2005 Nationwide Survey
}

\author{
Jessica Wilbarger ${ }^{1}$ and Susannah Howe ${ }^{2}$
}

\begin{abstract}
This work further details a survey of engineering capstone design courses nationwide conducted in 2005. The survey is a follow-up to one conducted in 1994 by Todd et al., reprising the questions of its predecessor plus requesting additional information. We implemented the 2005 survey online, with requests sent via email to representatives of all ABET-accredited engineering programs (1724 programs at 350 institutions, as of 2004). The online survey yielded a strong response, with 444 programs from 232 institutions submitting responses. This corresponds to a $26 \%$ response rate from engineering programs and a $66 \%$ response rate from institutions. This paper focuses on the additional questions in the 2005 survey that provide further insight about the current state of engineering capstone education. In particular, the paper discusses results relating to course management, student deliverables and evaluation, program funding, and perceived capstone course success.
\end{abstract}

Index Terms - Capstone design courses, Capstone funding, Capstone survey, Engineering capstone education.

\section{INTRODUCTION}

Capstone design courses offer engineering students a culminating design experience on an applied engineering project. With a longstanding history reinforced by support from the Accreditation Board for Engineering and Technology (ABET), these courses have become common in engineering departments across the United States. The composition of capstone courses, however, varies widely. In 1994, Todd et al. [1]-[2] conducted a survey of engineering departments throughout North America to capture educational and logistical practices in capstone design courses at the time.

In 2005, we completed a survey of engineering capstone design courses to collect current practices and examine trends in the past decade. The 2005 survey reprised the questions of its 1994 predecessor, augmented with additional questions on course management, student deliverables and evaluation, and program funding. The results of the 2005 survey have been roughly divided into two categories: those that directly correspond to the 1994 survey and those that represent new questions in the 2005 survey. Results in the first category, those that succeeded the 1994 responses, were presented (in comparison with the corresponding 1994 data) at ASEE 2006 [3]. This paper, on the other hand, focuses on the second category: the additional 2005 survey results without a 1994 counterpart. Since these questions address several areas of capstone design courses in depth, the data provide further insight about the current state of engineering capstone education. The results of the survey are a first step in understanding, assessing, and ultimately improving engineering capstone education nationwide.

\section{METHODS}

So as to discern trends developing in the past decade and also to acquire a general picture of the state of capstone engineering education today, we designed the 2005 survey to include most of the questions from its 1994 predecessor [1], with some new questions regarding course details, student responsibilities and deliverables, and project funding. After soliciting feedback from several colleagues in capstone education, we posted the final version as an online survey with seven sections and a total of 57 questions. Following a cover page soliciting contact information for the respondent, the survey questions focused on course details, faculty involvement, project information, feedback from course participants, project funding, and industry sponsorship. A page was devoted to any further comments from respondents, with several open-ended questions as suggestions. (See www.smith.edu/engin/designclinic/survey.html to access the survey.)

In May 2005, we sent an email to the department chair of each accredited undergraduate engineering program in the United States, asking that it be forwarded to the person in charge of each capstone course. If the program had no capstone courses, the department head was asked to indicate this on the initial page, and submit that page. Names and contact information for these programs had been compiled earlier using ABET's online listing of accredited engineering programs as of 2004 [4]. We sent a follow-up email in June to all those who had not yet responded, then another in October to a targeted group of still non-responding institutions: ranked schools from U.S. News and World Report [5]-[6]. Responses were accepted until early November 2005.

Of the 1724 programs at 350 institutions surveyed, 444 programs from 232 institutions replied, yielding response rates of $26 \%$ among programs and $66 \%$ among institutions. The results of the online survey (responses plus comments) were compiled and processed electronically. Of the 444 respondents, $98 \%$ offer some form of capstone design course or project.

\footnotetext{
${ }^{1}$ Jessica Wilbarger, Picker Engineering Program, Smith College, jwilbarg@smith.edu

${ }^{2}$ Susannah Howe, Design Clinic Director, Picker Engineering Program, Smith College, showe@smith.edu 1-4244-0257-3/06/\$20.00 @ 2006 IEEE

$36^{\text {th }}$ ASEE/IEEE Frontiers in Education Conference

October 28 - 31, 2006, San Diego, CA 
Session T1E

\section{SURVEY RESUlTS AND DISCUSSION}

This section details and discusses the specific results from the 2005 survey that were not captured in 1994. As such, it provides additional depth about the current state of capstone education. The results are organized in the following five categories: survey respondents, course information, students, funding, and success.

\section{Survey Respondents}

This section describes the profile of the survey respondents based on type of department and age of capstone program. Table I shows the percent of respondents sorted by department. The specific categories were chosen for ease of comparison; departments were grouped as closely as possible.

TABLE I

SURVEY RESPONDENT DEPARTMENTS (N=444)

\begin{tabular}{ll}
\hline Department & $\%$ Responses \\
\hline Chemical Engineering & 14 \\
Civil/Environmental Engineering & 14 \\
Electrical/Computer Engineering & 20 \\
Industrial Engineering & 6 \\
Mechanical/Aerospace Engineering & 19 \\
Other Engineering & 28 \\
\hline
\end{tabular}

Note that since many departments represent several related disciplines, the categories reflect more than just the listed department. For example, "Chemical" includes pure chemical engineering departments, as well as chemical and biomolecular, chemical and biological, and chemical and biomedical. Pure biomedical engineering departments, on the other hand, were grouped in "Other Engineering". Similarly, some of the "Civil/Environmental" departments include architecture or surveying and some of the "Industrial" departments include manufacturing or systems. The "Other Engineering" category included such departments as biomedical, geological, materials, mining, nuclear, and petroleum engineering as well as general engineering (15\% of the "Other Engineering" category). As is clear from Table I, the respondent population for the 2005 survey spanned the disciplines, with no single discipline overwhelming the others. The substantial number of "Other Engineering" departments responding to the 2005 survey, especially compared with the 1994 results, likely reflects the rise of specialized, interdisciplinary, and general engineering departments in the past decade [7].

The age of respondents' capstone courses (Table II) shows a similar variety, though respondents tended slightly more to represent fairly recent capstone courses. In fact, over half of the capstone courses are less than ten years old (in their current form), while a full two-thirds arose after 1990. Ages are well distributed even throughout this subcategory; perhaps most notable is that $22 \%$ of the capstone courses are less than four years old. The total range is also extensive. The youngest two capstone courses, from both a biomedical and an industrial engineering program, were reported as six months old in 2005, while one mechanical engineering department offers one that is 80 years old.

TABLE II

HOW LONG HAS THIS COURSE EXISTED IN ITS PRESENT FORM? (N=400)

\begin{tabular}{ll}
\hline Age Range (years)* & $\%$ Responses \\
\hline $40+$ & 3 \\
$30-39$ & 4 \\
$20-29$ & 15 \\
$15-19$ & 11 \\
$10-14$ & 22 \\
$5-9$ & 23 \\
$0-4$ & 22
\end{tabular}

* Note, responses are as of 2005 .

\section{Course Information}

This section concerns practices within the capstone course itself. The survey asked questions about types of courses, the timing of instruction and project work, the role of other departments, and the developments of student teams. Responses to many of these questions were discussed in detail in the previous paper [3] in comparison to data from the 1994 survey. In this paper, those results are presented briefly as background, while responses to questions on type of instruction offered, presentation of student deliverables, and determination of final grades are examined in more detail. Status of participating students and the categorization of projects are also discussed.

Most capstone courses were reported to be one to two semesters in duration and consist of both classroom instruction and a project, most often conducted simultaneously. A question on the type of teams revealed that while most capstone courses were based on departmental student teams, over one third incorporated interdepartmental or interdisciplinary teams. A follow-up question asked who participated in these interdisciplinary types of courses. Mechanical, electrical and computer engineering departments were the most frequent responses, but small percentages of biomedical, chemical, aerospace, business, and many other departments were also noted.

One question asked about methods of handling classroom instruction specifically in such interdepartmental cases; Table III displays the results. A plurality, $35 \%$, of respondents offer a single course section for all participating students; nearly a quarter divide course sections and instruction by discipline. Sixteen programs combine the two formats, while $20 \%$ offer no formal instruction at all. The varying sizes of programs and number of faculty involved with interdepartmental capstone design may account for these divides; from the responses written in, different philosophies toward the capstone course itself may also play a role. Many comments emphasized that only related disciplines such as electrical and computer engineering and computer science share course instruction, while others made the class available to students across the physical and social sciences, or in one case opened it to the entire student body.

October 28 - 31, 2006, San Diego, CA 
TABLE III

WHICH BEST DESCRIBES THE CLASS INSTRUCTION? $(\mathrm{N}=156)$

\begin{tabular}{ll}
\hline Course Structure & $\%$ Responses \\
\hline $\begin{array}{l}\text { One course section with the same instruction offered to all } \\
\text { engineering students }\end{array}$ & 35 \\
$\begin{array}{l}\text { Separate course sections and instruction for different } \\
\text { disciplines (i.e. electrical vs. mechanical engineering) }\end{array}$ & 24 \\
$\begin{array}{l}\text { Different disciplines receive both common and discipline- } \\
\text { specific classroom instruction }\end{array}$ & 11 \\
$\begin{array}{l}\text { No formal class instruction } \\
\text { Other }\end{array}$ & 20 \\
\hline
\end{tabular}

Within the course itself, the programs surveyed have explored seemingly endless combinations of presenting and evaluating student work, to the extent that methods of assessing student progress become difficult to categorize. Varied interpretations of the survey questions may have blurred the categories further. For instance, one question asked about the type and number of student presentations. Responses are shown in Tables IV and V. It is interesting to note that $8 \%$ of respondents have no formal final presentation, while a few programs arrange for more than four per team. Those who marked "Other" noted that it varied between groups, and several said they placed emphasis on written reports rather than presentations. However, one cannot present this data without considering that a "formal" presentation may have meant an in-class progress report to one respondent, and a campus-wide showing to another.

TABLE IV

HOW DO STUDENTS PRESENT THEIR WORK? ( $\mathrm{N}=392)$

\begin{tabular}{ll}
\hline Type of Presentation & $\%$ Responses \\
\hline Informal Interim Presentation & 59 \\
Formal Interim Presentation & 56 \\
Formal Final Presentation & 92 \\
Design Review & 45 \\
Other & 18 \\
\hline
\end{tabular}

TABLE $\mathrm{V}$

HOW OFTEN DO STUDENTS PRESENT THEIR WORK?

\begin{tabular}{lll}
\hline Type of Presentation & Number of Times & $\%$ Responses (of N) \\
\hline Informal Interim & $1-5$ & 67 \\
$(\mathrm{~N}=161)$ & $6-10$ & 12 \\
& $11-20$ & 6 \\
& $21+$ & 15 \\
\hline Formal Interim & 1 & 52 \\
$(\mathrm{~N}=158)$ & $2-3$ & 37 \\
& $4-5$ & 7 \\
& $6+$ & 4 \\
\hline Formal Final & 1 & 81 \\
$(\mathrm{~N}=182)$ & $2-3$ & 18 \\
& $4+$ & 1 \\
\hline
\end{tabular}

Another question asked about determining final grades for individuals working in teams. Responses in Table VI show which factors are considered in the final grade. Peer evaluations, as well as evaluations of individual and group deliverables throughout the term are each used by about half of programs, while a more notable finding is that $14 \%$ of respondent programs do not use evaluations of final group deliverables at all.

TABLE VI

HOW ARE INDIVIDUAL FINAL GRADES DETERMINED? $(\mathrm{N}=376)$

\begin{tabular}{ll}
\hline Source of Grade (Factor) & \% Responses \\
\hline Evaluation of individual deliverables throughout the term & 53 \\
Evaluation of group deliverables throughout the term & 67 \\
Evaluation of final group deliverable & 86 \\
Evaluations by other team members & 57 \\
Other & 31 \\
\hline
\end{tabular}

Table VII details the percentage of the final grade represented by each factor. (The responses were grouped into quartiles, with those answering 100\% receiving a separate category. The letters represent the quartile ranges of factor weights: $A=0-24 \%, \quad B=25-49 \%, \quad C=50-74 \%, \quad D=75-99 \%$, $\mathrm{E}=100 \%$.) Here, a surprising theme is the number of programs that give full weight to a single factor. Some base final grades only on group deliverables, while $2 \%$ base them solely on group evaluations. Written comments suggested that attendance, class participation, and evaluations by industry members also often affected grades, while some noted specifically that grades were subjective evaluations rather than precisely categorized numbers.

TABLE VII

FACTORS AND WeIGHTS CONTRIBUTING TO FINAL STUDENT GRADES

\begin{tabular}{llllll}
\hline Source of Grade (Factor) & \multicolumn{5}{c}{ \% Responses (of N)* } \\
& A & B & C & D & E \\
\hline Indiv. Deliverables Throughout $(\mathrm{N}=176)$ & 48 & 36 & 14 & 0 & 2 \\
Group Deliverables Throughout $(\mathrm{N}=210)$ & 40 & 40 & 15 & 3 & 2 \\
Final Group Deliverable (N=284) & 8 & 35 & 39 & 12 & 6 \\
Other Team Members' Input $(\mathrm{N}=175)$ & 80 & 17 & 1 & 0 & 2 \\
\hline * Factor weights: $\mathrm{A}=0-24 \%, \mathrm{~B}=25-49 \%, \mathrm{C}=50-74 \%, \mathrm{D}=75-99 \%, \mathrm{E}=100 \%$
\end{tabular}

Two survey questions asked in general terms about the status of students and design projects. When asked whether their capstone programs involved undergraduate or graduate students, only $5 \%$ of respondents $(\mathrm{N}=384)$ noted including graduate students, most often as less than one quarter of the total number of students. Additionally, a question on how the institution viewed the design projects revealed a very strong tendency to consider them academic projects rather than research. Indeed, $98 \%$ of respondents $(\mathrm{N}=244)$ viewed design projects as an academic endeavor; based on their comments, most respondents seemed to feel strongly that categorizing projects as research dilutes their educational value.

\section{Students}

Within categories of "Course", "Project", and "Industry", the survey asked questions relating specifically to students, ranging from workload and time management to number of

October 28 - 31, 2006, San Diego, CA 
students per team and teams per project. The data providing more of a statistical profile of students in a program were discussed in the previous paper [3] and compared to results from the 1994 survey. This paper focuses mainly on data regarding student practices within the course itself: how many hours students spend, how they schedule meetings, develop timelines, and travel to sponsors.

According to the survey respondents, students are most likely to work in teams of 4 to 6 members, though $4 \%$ $(\mathrm{N}=377)$ of programs do have teams of ten or more and $18 \%$ have some students work individually. A question on number of students per faculty member revealed that a 1 to 5 ratio is most common, though responses ranged from 1 to $20+$ ratios to a few programs that had more faculty than students. Finally, while almost all programs assign one team per project, $12 \%$ of respondents $(\mathrm{N}=363)$ assign an average of two to three teams for every project and $17 \%$ assign four or more.

Numbers of students per team, number of teams per project, length of course, and other factors clearly influence the number of hours team spend on a project. The responses to the survey question about total team hours ranged from 50 to 1500 or more hours, clearly depending on demands that vary from program to program. Comments made it clear, however, that students were expected to spend as much time as necessary to complete a project.

Two questions on the need for research and travel demonstrated the varying levels of student time different capstone projects demand. Most programs reported that substantial outside research is necessary to complete a project, but $12 \%$ of respondents $(\mathrm{N}=384)$ indicated that in fact projects required no outside research. A question directed specifically to those with outside sponsors asked how many trips student teams make to their sponsor; results are shown in Table VIII below. A strong majority, $83 \%$ of teams $(\mathrm{N}=239)$, visit their sponsor at least once, but about half visit only once or twice while the rest may travel from a few to 11 or more times; many comments noted weekly visits. Additionally, one can hardly assess the impact of travel on student time without considering the location of the sponsors students visit. Thus it is vital to note that of the 235 respondents who involve outside sponsors, $77 \%$ have at least some local sponsorship (within twenty miles) and $17 \%$ have entirely local sponsorship; on the other hand, $47 \%$ involve at least some sponsors located over one hundred miles from the institution.

TABLE VIII

NUMBER OF TEAM TRIPS TO SPONSORS ( $\mathrm{N}=150)$

\begin{tabular}{ll}
\hline Number of Team Trips & \% Responses \\
\hline 1 & 15 \\
2 & 34 \\
$3-5$ & 34 \\
$6-10$ & 11 \\
$11+$ & 6 \\
\hline
\end{tabular}

Another question focused on how a program ensures students are able to meet and work on the project. As Table IX shows, respondents seem evenly divided between leaving it entirely up to the students, scheduling a specific laboratory section, or using a combination of the two. Comments written in suggest attempts to demand responsibility but provide support: most state that the students must take initiative to meet, but also indicate that time is built into the general schedule of capstone students. Some responding programs, for instance, alternate formal instruction periods with "free" days, or arrange for blocks of time when no classes can be scheduled. For many programs, each group will also meet weekly with the instructor or a separate faculty advisor.

TABLE IX

HOW DO YOU ENSURE STUDENTS CAN MEET TO WORK? $(\mathrm{N}=414)$

\begin{tabular}{ll}
\hline Answer & $\%$ Responses \\
\hline $\begin{array}{l}\text { Arranging group work time is entirely the student's } \\
\text { responsibility. }\end{array}$ & 39 \\
$\begin{array}{l}\text { Capstone course includes a lab section specifically for } \\
\text { working on the project. }\end{array}$ & 36 \\
$\begin{array}{l}\text { Some part of a lab section is set aside for group work on } \\
\text { project, but students are responsible for finding other } \\
\text { meeting times. }\end{array}$ & 27 \\
Other & 15 \\
\hline
\end{tabular}

Respondents were also asked if students were given a detailed timeline as the beginning of the project, or expected to develop their own. Responses to this question $(\mathrm{N}=392)$ seem to place greater responsibility on the students, with $68 \%$ leaving students to develop independent timelines and less than a third giving students a schedule for the project cycle. However, the overlapping responses and written comments suggest a combination is most commonly used. Instructors give general guidance such as "milestone" due dates for large deliverables, and leave more incremental time management to the group's discretion. Such comments emphasized a trend in many responses concerning student work: that a capstone project places rigorous demands on students, but in an atmosphere of guidance and support.

\section{Funding}

A section of the 2005 survey was devoted entirely to funding and asked both for general estimates of a capstone project's cost, and more specifically about the nature and sources of funds, and the kind of expenses they cover. Discussion in the previous paper [3] dealt largely with funding by industry sponsors, while the questions presented here apply to all survey respondents, whether or not their projects were industry-sponsored. They cover issues such as direct and indirect cost, what the costs cover, and the general sources and forms of funding provided.

The survey data reveal that $52 \%$ of respondents $(\mathrm{N}=341)$ receive some funds from industry sponsors, though $68 \%$ report funds from their institution and nearly a third receive monetary contributions from students. Both the sponsor and the institution cover the entire cost of the project for about a quarter of respondents ( $\mathrm{N}=155$ and 182, respectively), while student contributions were usually smaller. Additionally, these sponsors most often funded the project directly, rather than sponsoring the institution.

October 28 - 31, 2006, San Diego, CA 
With respect to funding in general, the responses revealed that not only amounts, but the views toward and methods of accounting for project cost varied tremendously by institution. The survey asked for a total of direct and indirect costs, and received responses ranging from zero to $\$ 10,000$ with many commenting that they could not track or simply did not know the amount. The 284 responses were distributed between zero and $\$ 10,000$ but with a definite emphasis towards the $\$ 1-\$ 250$ range, which represented a quarter of respondents.

Respondents also answered a question on what the indirect cost covered, and their equally varied responses may explain the wide range of reported total cost. For instance, of 277 respondents, $37 \%$ reported faculty time as a source of indirect cost, 34\% listed departmental support, and 20\% noted institutional overhead, while smaller percentages listed outside consultants, developmental support and a variety of expenses ranging from guest speakers to tool development. There was nearly a consensus, however, on a question about source of funding for indirect costs: $86 \%$ of respondents $(\mathrm{N}=153)$ said the institution covered at least some of it, while $24 \%$ listed an outside sponsor as a resource as well. When asked if institutional overhead was charged to external funds, (i.e. was not covered by the institution), however, $98 \%$ of 218 respondents said no.

Determining the amount and sources of direct cost seemed more straightforward: though responses still covered a wide range, there seemed to be more areas of common practices. As Table X shows, for instance, $68 \%$ of respondents reported that their average direct cost per project ranged from $\$ 1-1000$, while less than $5 \%$ reported average direct costs above $\$ 5,000$. Comments written in throughout the survey suggest that many capstone courses do not involve a physical end product, but a more conceptual solution.

TABLE X

WHAT IS THE DIRECT COST PER PROJECT $(\mathrm{N}=359)$

\begin{tabular}{ll}
\hline Answer & $\%$ Responses \\
\hline$\$ 0$ & 13 \\
$\$ 1-1000$ & 68 \\
$\$ 1000-5000$ & 15 \\
$\$ 5000-10,000$ & 2 \\
$\$ 10,000+$ & 3 \\
\hline
\end{tabular}

Table XI shows the responses to the question of what the direct costs cover. Many respondents selected multiple categories, with supplies and hardware as the most popular. Software and travel also factor into direct cost for many respondents, while miscellaneous costs such as printing, phone calls, and laboratory fees were listed by those who checked "Other". The survey also asked for percentage of direct cost devoted to each source, with interesting results: software, supplies and travel tended to represent less than one-third of direct cost, while hardware was most likely to be at least onethird, if not two-thirds or higher, of the direct cost. Every category also contained a small percentage of respondents for whom that category represented their entire direct cost.

TABLE XI
WHAT DOES THE DIRECT COST COVER? $(\mathrm{N}=318)$

\begin{tabular}{ll}
\hline Answer & $\%$ Responses \\
\hline Supplies & 63 \\
Hardware & 55 \\
Software & 36 \\
Travel & 26 \\
Other & 26 \\
\hline
\end{tabular}

A final question on capstone project funding asked if funds were offered in the form of gifts, grants or return for expenses. The responses, detailed in Table XII show that slightly less than half of respondents receive funds as gifts, while grants and return for expenses provide funding for about a quarter each of respondents. Although respondents were allowed to select more than one of these answers, most chose only one, indicating a notable consistency in the form of funding.

TABLE XII

WHAT IS THE FORM OF FUNDING? $(\mathrm{N}=280)$

\begin{tabular}{ll}
\hline Answer & \% Responses \\
\hline Grants & 23 \\
Gifts & 44 \\
Return for Expenses & 27 \\
Other & 6 \\
\hline
\end{tabular}

\section{Success}

Nearly $90 \%$ of respondents reported some established method of determining a capstone project's success, suggesting that most institutions view assessment of outcomes as an important factor of the capstone design process. Questions in the survey asked specifically how students and faculty "generally rate the educational value of the course" and how sponsors "generally rate the effectiveness of the project outcome"; responses are presented in Table XIII.

TABLE XIII

RATINGS OF CAPSTONE COURSES BY FACULTY, STUDENTS, AND SPONSORS $10=$ HIGHEST RATING, $1=$ LOWEST RATING; $\mathrm{N}=402$

\begin{tabular}{llll}
\hline $\begin{array}{l}\text { Average } \\
\text { Rating }\end{array}$ & Faculty* & Students* & Sponsors + \\
\hline Don't Know & 12 & 4 & 31 \\
10 & 32 & 28 & 23 \\
9 & 17 & 20 & 15 \\
8 & 22 & 30 & 14 \\
7 & 9 & 12 & 9 \\
6 & 2 & 2 & 2 \\
5 & 2 & 2 & 2 \\
4 & 1 & 0 & 1 \\
3 & 1 & 1 & 0 \\
\hline Mean Rating & 8.6 & 8.5 & 8.4 \\
\hline
\end{tabular}

* Rating by faculty and students is of "educational value of the course" + Rating by sponsors is of "effectiveness of the project outcome"

While the reported average ratings by all parties were between 8 and 9 on the one to ten scale, it is important to note the small but present number of respondents with low ratings: in fact, seven programs had ratings of 4 or lower in one of the three categories. (It is worth commenting that the survey did

\section{1-4244-0257-3/06/\$20.00 @ 2006 IEEE}

October 28 - 31, 2006, San Diego, CA

\section{$36^{\text {th }}$ ASEE/IEEE Frontiers in Education Conference}


not specifically ask how the faculty respondents gathered these data, just what the average ratings were; additional research on how programs are assessed internally and externally could elaborate further.)

\section{CONCLUSIONS}

This work discusses responses from a survey of engineering capstone design courses nationwide that we conducted in 2005. We developed the survey online, solicited responses via email, and received a response rate of $66 \%$ among institutions and $26 \%$ among programs, for a total of 444 programs from 232 institutions. As a successor to a 1994 survey of capstone courses [1], the recent survey reprised the questions of its predecessor in addition to some new questions. This paper details the additional questions that do not have documented 1994 counterparts.

The results of these additional questions are divided into five main categories: survey respondents, course information, students, funding, and success. The outstanding trends are reviewed below, with more details available in the body of the paper. The survey respondents represented a fairly even distribution across engineering departments; half of the capstone programs represented are less than ten years old. Regarding course information, respondents report wide variation in class instruction for interdepartmental students, types and frequency of student presentations, and strategies for determining student grades. In completing their design projects, students commit a wide range of hours, are usually responsible for finding time to meet with their teammates, and often develop their own timelines. In addition, they tend to complete outside research and, if they have a sponsor, are likely to visit their sponsor at least twice. Levels of funding and methods of accounting for costs vary widely by institution, though direct costs are most often less than $\$ 1000$ per project, and tend to cover supplies and hardware, among other things. Funds to support these costs are most often received as gifts, return for expenses, or grants. Overall, the educational value of capstone courses and the effectiveness of project outcomes are rated highly by faculty, students, and sponsors.

This work was motivated by a desire to better understand engineering capstone courses and practices employed by capstone educators on a national scale. The 2005 survey results serve as (1) a compilation of logistical and implementation information about current engineering capstone education programs and (2) a springboard for future research on the subject to enrich and advance capstone education in engineering. Indeed, by first knowing what the current practices are, and then measuring the effectiveness of these practices, the engineering capstone community can collectively improve the delivery and success of capstone education for its students. Suggested future work includes follow-up surveys on targeted areas, such as funding and intellectual property, coupled with longitudinal efforts and assessment results.

\section{ACKNOWLEDGMENT}

We gratefully acknowledge the many engineering faculty nationwide who contributed their time and responses to the 2005 capstone survey. Our apologies to those who did not receive the survey request. We also extend special thanks to the architects of the 1994 survey for laying the foundation of capstone course understanding and to Bob Todd, Keith Stanfill, Steve Beyerlein, Catherine Skokan, Dwight Wardell, and Jack Zable for assistance with the 2005 survey development.

\section{REFERENCES}

[1] Todd, R., Magleby, S., and Sorenson, C., "Nationwide Senior Design Course Survey", 1994, Brigham Young University, College of Engineering and Technology. Paper copy received from Robert Todd, June 2004.

[2] Todd, R., Magleby, S., Sorenson, C., Swan, B., and Anthony, D., "A Survey of Capstone Engineering Courses in North America", Journal of Engineering Education, April 1995, pp. 165-174.

[3] Howe, S. and Wilbarger, J., "2005 National Survey of Engineering Capstone Design Courses", Proceedings of the 2006 ASEE Annual Conference and Exposition, ASEE, 2006.

[4] Accreditation Board for Engineering and Technology, ABET-Accredited Programs, www.abet.org/accredit.asp, Accessed October 2004.

[5] "Schools of Engineering", U.S. News \& World Report, Vol. 136, Issue 12, 12 April 2004.

[6] "Best Undergraduate Engineering Programs", U.S. News \& World Report, Vol. 129, Issue 10, 11 September 2000.

[7] Accreditation Board for Engineering and Technology, Accreditation Statistics - Part B: Accreditation Trend Data, 2005, www.abet.org/ Linked\%20Documents-UPDATE/04-AR\%20Statistics.pdf, Accessed January 2006. 